\title{
Infant Vocalizations and Early Home Language Environment
}

\author{
Hyunjoo $\mathrm{Yoo}^{\mathrm{a}}$, Seunghee $\mathrm{Ha}^{\mathrm{b}}$ \\ ${ }^{a}$ Communicative Disorders, University of Alabama, Tuscaloosa, USA \\ ${ }^{b}$ Division of Speech Pathology and Audiology, Audiology and Speech Pathology Research Institute, Hallym University, Chuncheon, Korea
}

Correspondence: Seunghee $\mathrm{Ha}, \mathrm{PhD}$ Division of Speech Pathology and Audiology, Audiology and Speech Pathology Research Institute, Hallym University, 1 Hallymdaehak-gil, Chuncheon 24252, Korea

Tel: $+82-33-248-2215$

Fax: +82-33-256-3420

E-mail: shha@hallym.ac.kr

Received: March 25, 2021

Revised: April 26, 2021

Accepted: April 26, 2021
Objectives: It is well known that infant-directed speech (IDS) facilitates early language acquisition. There is also growing evidence that adult-directed (ADS) or overheard speech may influence language learning. Given the importance of early language environment in infancy, greater attention must be paid to systematically investigating home language environment as well as relations between language input and infant volubility. The goals of this study were (1) to investigate the amount of IDS and ADS in a naturalistic environment, (2) to examine infant volubility across differing circumstances, and (3) to explore relations between caregiver volubility and infant volubility. Methods: Sixteen caregiver-infant dyads living in Korea participated in the study. Caregiver and infant vocalizations were recorded using all-day LENA (Language ENvironment Analysis) recorders in their homes as part of a longitudinal study. We quantified the number of infant speech-like vocalizations (i.e., protophones). We also estimated the amount of caregiver volubility. Generalized Estimating Equations (GEE) were conducted to address the research questions. Results: Results indicated that caregivers did not constantly talk to their infants. There was a significant difference in infant volubility between the IDS and No IDS circumstances. However, no significant difference was found between the ADS and No ADS circumstances. Infant volubility was found to be highest when caregiver volubility ranged in the middle. Conclusion: This study may support a midrange hypothesis which suggests that midrange interaction is optimal for infant development outcomes.

Keywords: Infant-directed speech, Adult-directed speech, Speech-like vocalizations, Caregivers, Language environment
영유아기의 언어-사회적 환경은 아동의 인지 및 언어발달에 중요 한 역할을 한다(Leung, Hernandez, \& Suskind, 2020; Romeo et al., 2018). 양육자의 언어 자극이 영유아의 말-언어발달에 미치는 영향 에 대해서는 오랜 시간 동안 많은 연구자들이 일관된 결과를 보고 하였다. Hart와 Risley (1995)는 양육자의 언어 자극이 아동의 언어 발달에 미치는 영향을 조사한 대표적인 연구로 양육자의 사회경제 적인 수준에 따라 아동이 노출되는 단어 수의 차이가 만 3세까지 최대 3 천만개에 달할 수 있다고 보고하였다. 이 연구의 타당성 및 결과의 일반화 가능성과 관련해서 최근까지 논쟁이 지속되기는 하 지만(Adair, Colegrove, \& McManus, 2017; Dudley-Marling \& Lucas, 2009), 이 연구를 계기로 그동안 학자들 사이에 이견이 많았던
언어 자극 및 환경과 아동의 언어발달 간의 관련성에 많은 관심이 집중되었고, 이 주제와 관련된 연구가 현재까지도 지속적으로 보고 되고 있다. 예를 들어, Hoff (2013)는 사회경제적인 수준에 차이가 있는 16-31개월 63명의 아동과 양육자의 상호작용을 두 차례 집에 서 녹화하고 아동과 양육자의 발화를 전사하여 연구하였다. 비록 짧은 시간 동안의 상호작용만을 포함하였고, 다른 요인들은 포함 하지 않았지만 두 번의 방문에서 나타난 아동들의 표현 어휘 차이 가 양육자의 언어 자극 특성(예: 수, 길이, 주제 유지 등)과 높은 관 련이 있는 것으로 보고하였다. Rowe (2012)는 50명 아동의 어휘 능 력과 양육자와의 상호작용 간의 관련성을 연구하였다. 사회경제적 인 요인을 통제하면 언어 자극의 양과 더불어 특히 질적인 특성(예: 
다양하고 복잡한 어휘의 사용, 탈문맥화된 문장 사용 등)이 아동 의 어휘 능력 발달에 영향을 주는 것으로 나타났다. Gilkerson 등 (2018)은 2-36개월 아동들의 발화를 수집하고 분석한 후 이 아동 들이 9-14세가 되었을 때 언어 및 인지발달 검사를 실시하였다. 그 결과, $18-24$ 개월 사이의 양육자와의 상호작용 수가 아동의 인지 및 언어발달과 관련이 높았다. 양육자의 발화 수는 언어발달과 상관 이 있는 것으로 나타났으나 사회경제적인 요인을 통제하였을 때에 는 관련성이 약화되었다. 이 연구 외에도 장난감 유형에 따른 양육 자의 발화 수 차이(Sosa, 2016), 청각장애 아동과 양육자와의 상호 작용(Sultana, Wong, \& Purdy, 2019), 미숙아와 양육자의 언어 자 극(Caskey, Stephens, Tucker, \& Vohr, 2011) 등 다양한 연령과 집단 을 대상으로 언어 자극 및 상호작용과 언어발달 간의 상관관계가 보고되고 있다. 최근에는 양육자의 언어 자극이 아동의 말-언어발 달을 넘어 읽기 능력 및 학습발달과 관련이 있다는 결과도 보고되 고 있다(Forget-Dubois et al., 2009; Parker, Boak, Griffin, Ripple, \& Peay, 1999). 이러한 연구결과를 근거로 발달 초기에 적절한 언어 환경을 조성하기 위한 부모교육을 정책적으로 시도하기도 한다 (Maloney, Converse, Gibbs, Levine, \& Beilock, 2015).

앞서 살펴본 것처럼 현재까지 다양한 연령과 집단을 대상으로 양육자의 언어 자극과 언어발달에 관한 연구가 점점 증가하고 있는 추세이다. 그러나 대부분 아동의 어휘 능력을 발달 지표로 사용하 는 경우가 많아 어휘 능력을 측정할 수 없는 어린 연령인 영유아 시 기의 발성발달과 양육자의 언어 자극에 관한 연구는 매우 부족한 실정이다. 또한 출판된 연구들의 경우에도 영아 및 양육자의 반응 에 초점이 맞추어져 있어 언어 환경적인 측면은 간과되어왔다. 예를 들어, 양육자와 영아의 상호작용 및 언어 자극에 관한 대부분의 선 행연구는 영아가 보이는 영아 지향어(infant-directed speech)에 대 한 선호 반응을 포함한 영아 지향어의 특성에 관한 연구(Cooper \& Aslin, 1990; Pegg, Werker, \& McLeod, 1992), 영아의 발성 유형에 따른 양육자의 반응 차이(Elmlinger, Schwade, \& Goldstein, 2019; Gros-Louis, West, Goldstein, \& King, 2006), 주고받기의 발달(Bateson, 1975; Trevarthen \& Aitken, 2001)에 관한 것이 주를 이루었다.

Oller 등(2019)은 영아기의 발성 산출과 언어 자극에 관한 연구 결과를 보고한 논문 중의 하나로 양육자의 두 가지 발화 조건에 따 른 영아의 원시발성 산출 비율을 보고하였다. 양육자 혹은 성인이 영아에게 직접 말을 거는 조건을 영아 지향어(infant-directed), 성 인끼리 대화하거나 전화 통화를 하여 영아가 간접적으로 성인의 언 어에 노출되는 조건을 성인 지향어(adult-directed)로 정의하고 영 아의 원시발성 비율이 생후 첫 달부터 1년 동안 어떻게 달라지는지 보고하였다. 연구에 따르면 생후 첫 달부터 양육자의 영아 지향어가
관찰된 녹음 자료에서 영아 지향어가 없는 경우와 달리 원시발성의 비율이 현저히 높았다. Caskey 등(2011)의 연구 역시 영아(미숙아) 의 발성과 양육자의 발화 산출량을 조사한 소수의 연구 중 하나이 다. 저자들은 그동안 연구가 거의 전무했던 신생아 집중 치료실에 있는 미숙아의 발성과 부모의 언어 자극 등 언어 환경에 대해 체계 적으로 조사하였다. 신생아 집중 치료실에 있는 미숙아들은 부모 의 언어 자극에 노출되는 정도가 제한적일 수밖에 없다. 연구자들 은 부모가 영아를 방문하는 시간대에 영아와 성인의 발성 및 발화 량이 증가하고 그에 따라주고받기의 양도 증가했다는 결과를 토대 로 성인의 언어 자극이 미숙아를 포함한 영아의 발성발달에 중요 한 역할을 한다고 제안하였다. Lopez, Walle, Pretzer와 Warlaumont (2020)는 13개월 영아의 발성과 양육자의 발화를 연구하였는데, 음 절성 옹알이를 많이 산출하며 양육자의 말소리 자극을 많이 받았 던 영아가 MacArthur-Bates Communicative Development Inventory $(\mathrm{CDI})$ 검사에서 표현 어휘의 점수가 높게 나타났다.

영아의 발성과 양육자의 발화 산출량에 관한 연구는 현재까지 출판된 논문의 수가 현저히 적다는 문제외에도 방법론적으로 심도 있게 고찰해야 할 요소가 있다. 첫째, 지금까지 대부분의 선행연구 는 양육자의 언어 자극과 영아의 말-언어발달 연구를 위해 연구실 에서 수집한 자료를 이용하였다. 연구실에서 자료를 수집하는 것 이 연구 목적에 따라 여전히 필요하지만 일상생활에서 산출되는 양육자의 언어 자극 양을 실질적으로 조사하기 위해서는 적절한 방법이 아닐 수 있다(Tamis-LeMonda, Kuchirko, Luo, Escobar, \& Bornstein, 2017). Fagan과 Doveikis (2017)는 이러한 제한점을 지 적하며 실제 일상생활에서는 연구실에서만큼 양육자가 영아에게 언어적으로 반응하지 않음을 보고하였다. 연구실에서 자료를 수집 한 선행연구에서는 대체로 70-80\%의 아동 발화에 양육자가 반응 하였다고 보고하였으나, Fagan과 Doveikis (2017)는 아동의 가정에 서 수집한 자료를 통해 양육자가 아동 발화의 $30 \%$ 정도에만 반응 하는 것으로 보고하였다. 이러한 차이에 대해 저자들은 연구실에 서 자료를 수집할 경우 양육자는 연구원들이 지켜보는 가운데 실 제보다 더 많이 반응하는 경향이 있다고 지적하였다. Yoo, Bowman과 Oller (2018) 역시 일상생활에서 수집한 자료를 바탕으로 양육자가 신생아의 원시발성에 대략 $10-21 \%$ 반응하였음을 보고하 여 연구실에서 수집한 자료와의 극명한 차이를 보여주었다. 연구실 이라는 공간의 제한점과 더불어 연구실에서는 대부분 30 분 내외 의 짧은 시간 동안 발화를 수집하므로 이를 통해서 결과를 도출하 는 방법 역시 영아 발성 및 양육자의 발화에 관한 대표성을 갖기 어 렵다. 이러한 제한점을 극복하기 위하여 최근에는 일상생활에서 긴 시간 동안 아동과 양육자의 자연스런 발성 및 발화를 수집할 수 
있는 Language ENvironment Analysis (LENA) 녹음기와 같은 기 기를 사용한 연구가 증가하고 있다.

둘째, 양육자의 발화 산출량을 산정하는데 있어 일관된 방법이 사용되지 않았다. 연구에 따라 서로 다른 방법 및 정의를 사용하여 연구들 간에 직접적으로 비교하고 통합된 결론을 도출하는데 제한 이 있다. 양육자의 언어 자극에 대해 연구를 할 때는 아동 지향어와 아동에게 노출되는 성인 전체 발화가 섞여 있어 이를 구분하여 명시 하는 것이 좋다. 연구에 따라 이를 영아/아동 및 성인 지향어로 구분 하거나(Oller et al., 2019) 직접 및 간접 발화로 구분하여 명시하기도 한다(Foushee, Griffiths, \& Srinivasan, 2016; Orena, Byers-Heinlein, \& Polka, 2020). LENA는 일상생활에서 자연스럽게 산출되는 발화 를 수집하고 분석할 수 있다는 장점이 있지만 발화 인식 알고리즘을 통한 분석이기 때문에 특정 발화가 아동과의 상호작용에서 산출된 아동 지향어인지 혹은 단순히 아동 가까이에서 다른 성인에게 말하 는 것인지 정확히 구분하기가 어렵다. 예를 들어, Suskind 등(2013)의 연구는 LENA 분석 소프트웨어에서 제공하는 성인 단어 수(Adult Word Count, AWC)를 사용하여 연구를 진행하였다. 저자들은 아 동이 노출된 성인의 전체 단어 수로 언어 자극을 정의하고 결과를 보고하였다. 이 연구 외에도 LENA에서 제공하는 성인 단어 수를 근 거로 언어 환경의 변화와 아동의 언어발달 간의 관계를 보고한 연구 들이 있다(Walle \& Warlaumont, 2015). 그러나 언급된 두 연구의 경 우 아동 지향어와 성인 지향어에 대한 구분이 명확하지 않은 제한적 인 방법을 통해 결론을 도출하였다. 따라서 이러한 연구들의 결과를 근거로 절대적인 성인 발화의 양이 언어발달에 중요하다고 결론을 내리기보다는, 성인 발화와 언어발달에 관한 더 많은 연구, 특히 성 인의 발화 유형을 세분하여 살펴보는 연구들이 필요하다.

국내에서도 국외의 상황과 다르지 않게 양육자의 언어 자극과 영아의 발성발달에 관한 연구가 미비한 실정이다. 양육자의 영아/ 아동 지향어 및 양육자의 언어 자극에 관한 연구가 일부 발표되고 있지만 국외에 비해서는 현저히 부족한 실정이다. 더욱이 현재 출 판된 연구의 경우에도 아동 지향어의 음향 음성학적 특성에 중점 을 준 연구나(Choi, 2012; Kim, 2009), 영아기 이후의 아동과 성인의 발화를 조사한 연구가 대부분이라(Lee \& Yim, 2017; Park \& Yim, 2015) 영아기에 중점을 둔 연구가 매우 필요한 실정이다.

본 연구에서는 말-언어발달의 기초로서 중요하지만 연구가 미비 했던 영아기의 일상적인 언어 환경과 영아의 발성 산출을 조사하였 다. 영아 지향어가 영아의 언어발달에 미치는 영향은 익히 알려진 사실이지만, 실제 일상생활에서 양육자가 사용하는 영아 지향어의 비율과 원시발성 간의 관련성을 알아보는 것은 추후 보다 심도 있 는 언어 환경 및 원시발성 발달의 분석과 부모교육 등을 위해 중요
하다. 또한 영아에게 직접적으로 말을 거는 경우 뿐 아니라 간접적 으로 성인의 언어에 노출된 경우에도 어휘 습득이 일어난다는 선 행연구(Floor \& Akhtar, 2006)에 따라 성인 지향어의 산출 비율도 연구에 포함하였다. 본 연구의 질문은 다음과 같다.

1. 일상생활에서 관찰되는 영아 및 성인 지향어의 비율은어떠한가?

2. 영아 및 성인 지향어 조건에 따라 원시발성 산출량에 차이가 있는가?

3. 영아 및 성인 지향어 산출 비율 변화와 원시발성의 산출 비율 이 관련이 있는가?

\section{연구방법}

\section{연구대상}

한국어권 영유아의 말-언어발달 연구를 위해 수집된 발성 및 발 화 종단 연구 녹음 자료(Jang \& Ha, 2020) 중 0-13개월의 자료가 본 연구에 포함되었으며, 이는 Yoo, Oller와 $\mathrm{Ha}$ (2021)의 연구대상과 동일하다. 종단 연구에 참여한 영아 16 명(남: 7 명 여: 9명)의 발성 자 료와 영아들의 주양육자 및 성인의 발화를 분석하였다. 연구에 참 여한 모든 영아는 정상 청력이며, 인지 및 신체발달상 특이 사항이 없는 것으로 보고된 일반 영아이다. 영아의 주양육자인 어머니의 연령은 25-43세이며(평균:33.1, SD: 3.43), 대학 졸업 이상의 학력이 15 명, 고등학교 졸업이 1 명이었다.

\section{자료수집}

자연스런 가정 내의 일상생활에서 아동의 발성과 양육자 및 성 인의 발화를 수집하기 위하여 영아의 가정에서 LENA 녹음기를 이 용하여 자료를 수집하였다. LENA 녹음기는 영아의 발성과 일상적 인 언어 환경(예: 양육자의 발성과 환경음 등)을 일일 최대 16 시간까 지 녹음할 수 있어 대표성이 높은 발성 자료를 수집할 수 있다 $(\mathrm{Xu}$ et al., 2008). 연구자(언어병리학 전공 대학원생)가 종단 연구에 참 여하는 영아의 가정에 방문하여 양육자와 인터뷰를 통해 영아의 전반적인 발달 상태, 아동과 양육자에 관한 기본 정보를 수집하였 다. 양육자는 처음 연구자가 방문한 날을 기준으로 일주일 이내에 일상적인 상황에서 첫 번째 녹음을 실시하였다. 이후 영아가 생후 18-20개월이 될 때까지 3개월마다 지속적으로 녹음을 실시하였다. 본 연구에서는 이 중 13 개월 이전에 수집된 자료를 이용하였다. 영 아가 종단 연구 참여를 마치게 되는 18-20개월이 되면 양육자에게 한국판 맥아더-베이츠 의사소통발달 평가 기록지(Korean MacArthur-Bates Communicative Development Inventories, K M-B CDI; $\mathrm{Pae} \& \mathrm{Kwak}, 2011)$ 를 실시하여 영아의 어휘발달에 관한 정보를 추 
가적으로 수집하였다. 본 연구의 모든 과정은 한림대학교 생명윤리 위원회의 승인을 받아 진행되었다(IRB 승인번호: HIRB-2016-0783-CCR).

\section{자료분석}

LENA 녹음기를 이용하여 각 영아의 가정에서 하루 동안 수집 된 녹음 자료는 우선 분석 소프트웨어인 LENA pro에 저장하였다. 대표성이 높은 자료를 분석하기 위하여 12-16시간 길이의 각각의 녹음 자료에서 무작위로 21 개의 5 분 분량 녹음 파일을 추출하였다. 영아마다 처음 연구 참여를 시작한 월령이 다르고 연구 참여 이후 3 개월 간격으로 자료가 수집되어 영아별로 분석된 자료의 월령과 수는 다르다. 영아 16 명이 생후 13 개월 이전까지 3-5회, 평균 3.9회 종단 자료 수집에 참여하였다. 본 연구에 사용된 영아의 월령별 녹 음 자료의 합은 총 63 개로 각 녹음 자료에서 21 개의 5 분 분량 파일 을 무작위로 추출하여 1,323 개의 녹음 파일을 생성하였다. 각 녹음 자료 당 추출한 파일의 수와 각 파일의 분량을 고려하면 총 6,615 분 의 녹음 파일이 본 연구에 사용되었다. Yoo 등(2021)에 각 영아의 월령별로 수집된 자료를 표로 제시하고 있어 보다 자세한 정보를 원하는 독자는 참고할수 있다.

언어병리학 전공 대학생 3 명과 대학원생 1 명이 본 연구의 분석에 참여하였다. 분석자들은 저자들로부터 영아의 원시발성과 유형, 언 어 환경 설문지에 대한 집중적인 훈련을 받은 후 분석을 실시하였 다. 5 분 녹음 파일 20 개에 해당하는 100 분의 음성 자료로 훈련을 통해 분석자들 간의 신뢰 상관 계수가 .80 이상에 도달한 후 본 연 구를 위한 분석을 시작하였다. 또한 분석자 편향을 최소화하기 위 하여 분석 시 영아의 개인 정보(예: 이름과 월령)를 제거한 후 분석 자들이 원시발성을 분류하도록 하였다. 원시발성 비율을 효율적으 로 분석하기 위하여 Action Analysis Coding \& Training (AACT; Delgado, Buder, \& Oller, 2010) 분석 소프트웨어를 사용하였다. $\mathrm{AACT}$ 는 분석자들이 녹음 파일을 들으며 제어창을 통해 쉽게 원 시발성 유형을 분류할수 있어 녹음 파일의 분석에 유용하다. AACT 에 대하여 보다상세한 정보를 얻기 원하는 독자는 Ha와 Oller (2019) 를 참고할수 있다.

먼저 분석자가 추출한 각 5 분 분량의 녹음 파일을 듣고 영아의 원시발성을 분류하였다. 원시발성을 분류하기 위하여 선행연구에 서 일관되게 사용된 발성 분류의 청지각적 기준을 사용하였다(Buder, Chorna, Oller, \& Robinson, 2008; Buder, Jarmulowicz, \& Oller, 2013; Oller, 2000; Oller et al., 2013, 2019; Yoo et al., 2021). 원시발성 의 유형 중 가장 산출 비율이 높고 성대 조절 발달에 중요한 의의를 가지는 세 가지의 유형 즉, 중성(vocant 또는 modal voice), 고성 (squeal) 및 탁성(growl)으로 먼저 영아의 원시발성을 분류하였다. 그러나 본 연구의 목적이 영아의 원시발성을 유형별로 조사하는 것 이 아니라 양육자 및 성인의 언어 자극에 따른 영아의 원시발성 산 출 비율을 조사하는 것이므로 최종 분석을 위해서는 각 유형별 원 시발성 산출량을 모두 합산하여 원시발성 산출량을 계산하였다. 원시발성과 유형에 대한 보다 자세한 정의와 설명은 Yoo 등(2021) 을 참고할 수 있다.

분석자가 녹음 파일을 듣고 영아의 원시발성을 분류한 후, 분석 자는 추가적으로 각 5 분의 녹음이 이루어진 시간대의 언어 환경 분석을 위하여 영아 및 성인 지향어의 산출 정도를 판단하여 기록 하였다. LENA 분석 소프트웨어는 성인 단어 수를 자동으로 분석 하여 제공하여 연구자 및 임상가들이 편리하게 이용할 수 있으나 분석 시 영아에게 직접 말을 거는 영아 지향어와 성인끼리 대화를 하는 성인 지향어의 구분이 명확하지 않다. 이러한 제한점을 보완 하기 위하여 본 연구에서는 영아가 노출되는 언어 환경을 세분화 하여 살펴보기 위한 방법으로 분석자가 각 음성 파일을 들은 후 성 인 발화의 유형(영아 및 성인 지향어)과 산출 비율을 판단하게 하였 다. 분석자가 언어 환경 및 녹음의 질에 관한 총 17 개의 질문에 1-5 까지의 Likert형 척도를 사용하여 판단하고 기록하였다. 17 개의 질 문 중 언어 환경에 관한 질문은 7 개였으며, 이 중 본 연구의 가설과 관련된 언어 환경 항목은 영아 지향어(infant-directed speech)와 성인 지향어(adult-directed speech)의 비율을 묻는 문항이다. 상세 히 설명하면 영아 지향어의 경우 성인이 영아에게 말을 건 비율을 판단하여 기록하도록 하였는데, 이때 말을 건넨 사람이 주양육자 뿐 아니라 다른 성인 혹은 아동도 포함될 수 있도록 하였다. 성인 지 향어의 경우 성인(혹은 아동)이 다른 성인과 직접 대화하거나 전화 통화를 하여 영아와 직접적으로 대화하지는 않았으나 영아가 간접 적으로 성인의 언어에 노출될 수 있는 상황인 경우 그 정도를 분석 자가 표기하도록 하였다. 분석자는 녹음 파일을 듣고 난 후 해당하 는 질문을 읽고 영아 및 성인 지향어의 산출 정도를 판단하여 1 (전 혀 없다: none), 2 (녹음 파일의 절반 미만: <half), 3 (절반 정도: half), 4 (절반 이상: > half), 또는 5 (거의 5 분에 가깝게: almost all) 중에서 해당하는 정도를 표기하였다. 이러한 설문을 통해 LENA 알고리즘으로 분석하기 어려운 각 5 분 녹음 파일에 대한 보다 상세 한 언어 환경 정보를 수집하였다.

\section{통계분석}

통계분석 시 분석자들의 언어 환경 판단 결과를 근거로 영아가 깨어있는 것으로 판단된 녹음 파일만을 포함하였다. 본 연구를 위 해 분석한 총 1,323 개의 5 분 녹음 파일 중에서 영아가 자고 있는 것 
으로 판단된 파일 86 개를 제외한 후 1,237 개의 파일의 결과만 통계 분석을 실시하였다. 영아가 노출되는 언어 환경의 정도와 영아의 발 성 산출량의 상관관계를 분석하기 위하여 종단 연구 자료의 분석 에 유용한 Generalized Estimating Equations (GEE)를 사용하였 다(Liang \& Zeger, 1986). 통계분석을 위하여 IBM SPSS Statistics (version 26)을 사용하였다.

\section{연구결과}

\section{일상생활에서 관찰되는 영아 및 성인 지향어의 비율}

연구실이 아닌 일상생활에서 자연스럽게 영아와 성인이 상호작 용을 한 자료를 바탕으로 영아 및 성인 지향어의 산출 비율이 어떻 게 관찰되는지를 조사하였다(Figure 1). 본 연구에 포함된 1,237개 의 5 분 녹음 파일 중 약 $10 \%$ (120개)가 일상적인 상황에서 성인이 영아에게 지속적으로 직접 말을 걸어 영아 지향어로만 구성된 경우 (설문지에서 5 로 표기된)로 관찰되었다. 다음으로 영아 지향어가 5 분의 절반 이상, 절반 정도, 절반 미만으로 차지하는 녹음 파일이 전 체 분석 파일 중 각각 $19 \%$ (241개), $23 \%$ (282개), $38 \%$ (469개)를 차 지하였다. 또한 5 분 동안 영아 지향어가 전혀 없었던 경우는 $10 \%$ 로 나타났다. 따라서 영아 지향어가 5 분의 절반 미만으로 나타난 파일 이 가장 높은 비율을 차지하였다. 성인 지향어의 경우 전체 1,237 개 의 파일 중에서 5 분 동안 성인 지향어가 전혀 관찰되지 않았던 경우 가 전체의 $49 \%$ 로 가장 높게 나타났다. 5 분 중에서 성인 지향어가차 지하는 비율이 증가함에 따라 성인 지향어가 관찰되는 파일의 비 율은 점점 감소하는 추세를 보였으며 성인 지향어로만 거의 모든 5 분이 구성된 파일 비율은 $3 \%$ 로 나타났다. 종합하면, 일상생활에서 성인은 영아에게 지속적으로 반응하고 말을 걸기 보다는 중간 정도 의 밀도로 영아에게 말을 걸거나 반응하는 것으로 나타났다.

\section{영아 및 성인 지향어 산출 조건에 따른 원시발성 산출량}

성인이 영아에게 직접 말을 걸거나 상호작용하는 정도를 1-5로 구분하였을 때, 성인의 영아 지향어가 전혀 없었던(1로 표기된) 녹 음 파일과 영아 지향어가 있었던(2-5로 표기된) 파일의 분당 원시발 성 산출 비율을 비교하였다. 성인의 영아 지향어가 없었던 경우, 원 시발성 분당 평균 산출량은 2.9 개, 영아 지향어가 산출된 경우는 3.6개로 나타났다(Figure 2). 영아 지향어 산출 유무에 따른 두 조건 에서 원시발성 산출량은 $\mathrm{GEE}$ 분석 결과, 통계적으로 유의미한 차 이를 보였다 $(p=.002)$.

성인이 영아에게 직접 말을 거는 경우뿐 아니라 영아의 주위에 서 간접적으로 이야기(예: 다른 성인과 대화 혹은 전화 통화)를 하 는 경우에도 영아의 원시발성 산출량에 차이가 있는지 알아보았 다. 성인 지향어가 산출되지 않았던 경우, 원시발성 분당 평균 산출 량은 3.4 개, 성인 지향어가 산출되었던 경우는 3.6개로 나타났다 (Figure 2). 두 조건의 원시발성 산출량은 $\mathrm{GEE}$ 분석 결과 통계적으 로 유의미하지 않았다 $(p=.075)$.

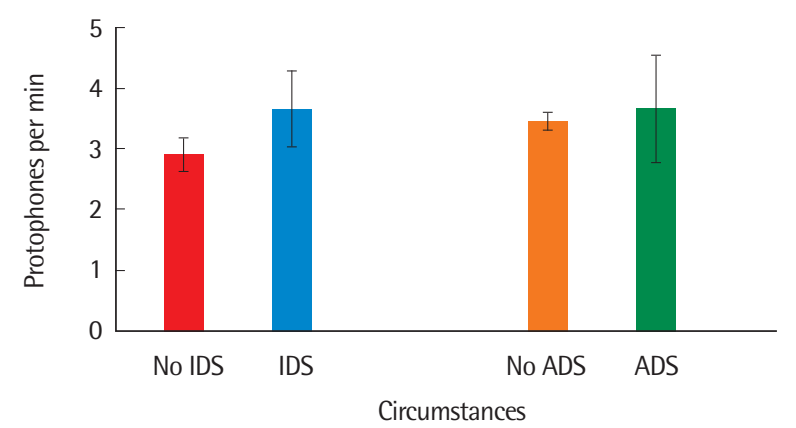

Figure 2. Protophone rates in differing circumstances. Infants produced significantly more protophones when there was infant-directed speech (IDS). However, adult-directed speech (ADS) was not related to changes of protophone rates.
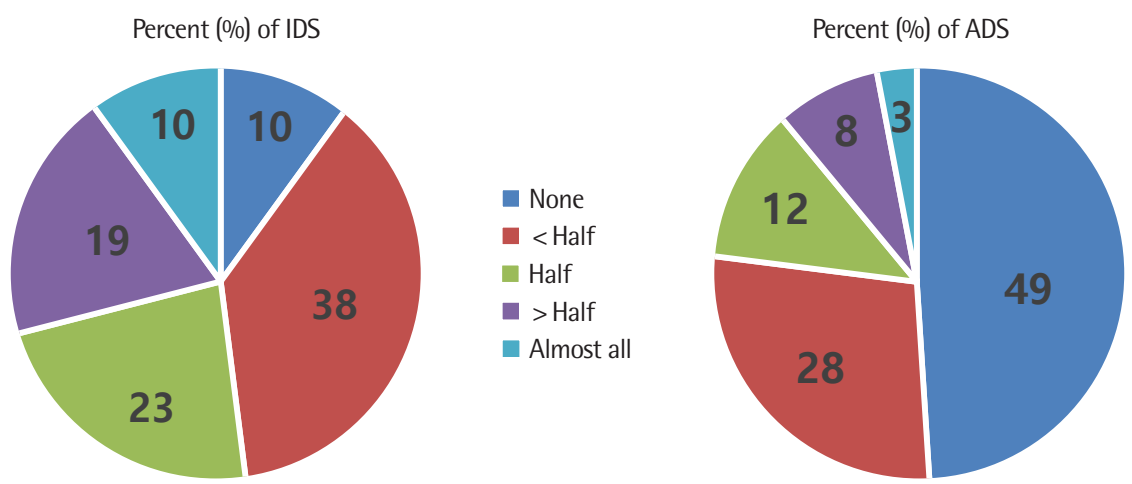

Figure 1. Percent of differing circumstances in 5-min segments. Caregivers did not constantly speak to infants during 5 min. Rather, in ordinary interactions the amount of IDS was reduced overall.

IDS = infant-directed speech; ADS = adult-directed speech. 


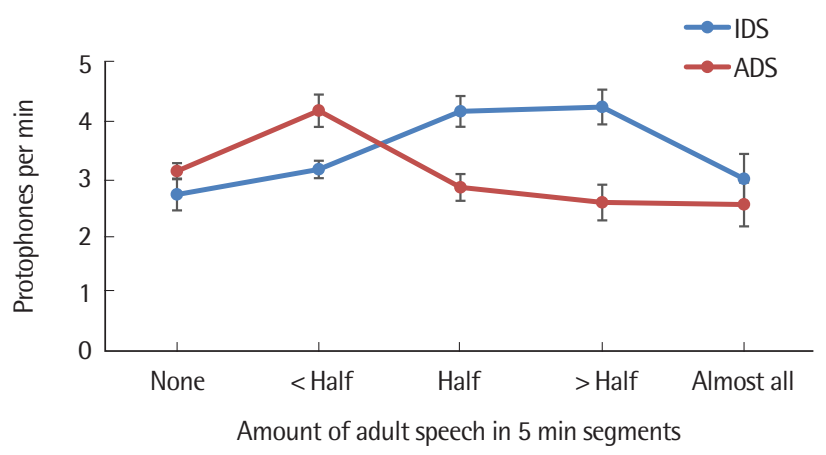

Figure 3. Protophones per min with regard to the amount of adult speech. Curvilinear relationship was found between the amount of infant-directed speech (IDS) and protophone rates.

ADS= adult-directed speech.

결과를 종합하면, 성인이 영아에게 직접 말을 걸거나 상호작용 을 하는 경우는 그렇지 않은 경우보다 통계적으로 유의미하게 원시 발성의 산출량이 증가하였다. 반면, 영아가 성인의 발화에 간접적 으로 노출되는 성인 지향어의 유무에 따라서는 영아의 발성 산출 량에 유의미한 변화가 없었다.

\section{영아 및 성인 지향어 산출 비율에 따른 원시발성 산출량}

Figure 3은 영아 및 성인 지향어의 산출 비율에 따라 1-5로 분류 하였을 때 그에 따른 원시발성의 산출량 변화 추이를 보여준다. 영 아 지향어의 산출 비율이 가장 높았던 경우보다 대략 절반 정도의 영아 지향어 산출 비율을 보였던 파일의 경우에 영아의 원시발성 산출량이 가장 높았다. 영아 지향어의 산출 비율에 따른 원시발성 의 산출량 변화를 알아보기 위하여 GEE 분석을 실시하였다. 성인 지향어를 공변량으로 설정하였을 때, 영아 지향어가 5 분 파일의 절 반 정도인 경우(4.2개, $p=.012$ )와 절반 이상인 경우(4.3개, $p=.001)$ 의 원시발성 분당 평균 산출량이 5 분에 가깝게 지속적으로 영아에 게 말을 걸었던 경우(3.0개)보다 통계적으로 유의미하게 높았다. 성 인 지향어의 경우에는 원시발성의 산출량에 변화가 있었지만 그 차 이가 통계적으로 유의미하지는 않았다. 전체적으로는 영아 지향어 의 산출 비율이 증가함에 따라, 영아의 원시발성 분당 산출량도 증 가하는 추세를 보였지만, 성인 지향어의 경우에는 비율이 증가함에 따라 오히려 영아의 발성 산출량이 대체로 감소하는 추세를 보였다.

\section{논의 및 결론}

본 연구는 일상생활에서 자연스럽게 나타나는 양육자 또는 성인 의 영아 및 성인 지향어의 산출 비율을 조사하고 언어 환경에 따른 영아의 원시발성 비율을 분석하였다. 말-언어발달에 중요하지만 연
구가 매우 미비한 생후 직후부터 일년 동안의 영아기 언어 환경을 실 제 녹음 자료와 설문을 통해 보다 상세히 조사하고 이에 따른 영아 의 원시발성 산출 변화추이를 보고한 것에 본 연구의 의의가 있다.

본 연구에서는 먼저 연구실이 아닌 일상생활에서 나타나는 영아 및 성인 지향어의 산출 비율에 대해서 조사하였다. 연구실에서 시 행되었던 선행연구의 경우 영아에 대한 양육자의 반응 비율이 대 략 70\% 이상으로 매우 높게 보고된다. 짧은 시간 연구실에서 수집 된 자료의 제한점도 있지만 언어적 반응과 비언어적 반응을 모두 포함된 경우로 인해 반응이 더욱 높게 나타났을 가능성도 있다. 본 연구에 따르면 일상생활에서 자연스럽게 나타나는 영아 지향어의 경우에는 5 분 녹음 파일을 기준으로 하였을 때 5 분의 중간 미만이 거나 중간 정도의 영아 지향어 산출을 보이는 파일의 비율이 가장 높았다. 이는 연구실 자료의 제한점에 대해 문제를 제기한 Fagan과 Doveikis (2017)의 연구와도 비슷한 결과이다. 또한 최근 국내 연구 에서도 일상생활에서 양육자가 영아의 원시발성에 무반응하는 경 우가 약 $60 \%$ 로 가장 많았고, 원시발성과 관련이 있는 반응은 약 $24 \%$ 로 보고하여(Lee \& Ha, 2021) 본 연구의 결과와 일치하였다. 이 와 같은 실제 언어 환경에 대한 자료는 정확한 양육자의 발화 빈도 를 산출하는 추후 연구나, 부모교육, 또는 산후 우울증이 있는 양 육자의 반응을 연구할 때 기초 자료로서 유용하게 사용될 수 있을 것이다.

다음으로 양육자가 영아에게 직접 말을 걸거나 영아와의 상호작 용을 반영하는 영아 지향어 조건에서 영아 지향어가 전혀 없는 조 건에 비해 영아의 원시발성 분당 산출량이 통계적으로 유의미하게 높았다. 반면에 성인 지향어의 경우에는 유무에 따라 원시발성 분 당 산출량에 차이가 있었지만 통계적으로 유의미한 수준은 아니었 다. 선행연구에서도 본 연구와 일치하는 결과를 보고하였다. Oller 등(2019)은 영아의 생후 $0,1,3,6,9,12$ 개월에 원시발성 비율과 양 육자의 영아 및 성인 지향어 산출 비율에 대해 보고하였다. 본 연구 의 결과와 마찬가지로 영아 지향어가 산출된 경우가 그렇지 않은 경우에 비해 모든 월령의 원시발성 비율이 통계적으로 유의미하게 높았다. 그러나 성인 지향어의 경우에는 그 차이가 영아 지향어에 비해 일관되거나 뚜렷하지 않았다. 더욱 흥미로운 것은 신생아 집 중 치료실에 있는 미숙아의 경우에도 영아 지향어가 산출되는 경 우 원시발성의 비율이 높았다. 그러나 저자는 양육자의 영아 지향 어 산출을 원시발성의 산출 비율 증가의 직접적인 원인으로 결론내 리는 것에는 신중해야 한다고 밝히고 있다. 그 이유는 양육자의 영 아 지향어 산출로 인하여 원시발성의 산출량이 직접적으로 증가하 였는지 혹은 영아의 발화가 증가하여 그에 따른 반응으로 양육자 의 영아 지향어도 증가하였는지 판단하기 위해서는 보다 심화된 연 
구가 필요하기 때문이다. 본 연구의 연구문제에 포함되지 않아 보 고하지는 않았으나 영아 울음의 경우, 양육자의 영아 지향어가 증 가함에 따라 영아의 울음 비율이 선형적으로 증가하였다. 이는 양 육자의 발화가 영아의 울음을 유발했다고 보기 보다는 영아의 울 음을 달래기 위해 양육자가 영아에게 직접적인 발화를 더 많이 산 출했다고 보는 것이 타당하다. 본 연구에서 성인 지향어가 5 분의 절 반 미만(<half)으로 산출된 경우를 제외하고 성인 지향어의 산출 비율이 증가할수록 영아의 발성 산출량은 대체로 감소하는 경향 을 보였다. 아동에게 노출된 성인의 단어 수가 아동의 어휘발달에 영향을 준다는 선행연구(Akhtar, Jipson, \& Callanan, 2001; Oshima-Takane, Goodz, \& Derevensky, 1996)를 고려하면 성인 지향어 산출의 증가가 노출된 단어 수의 증가를 반영하는 것이므로 원시 발성 산출량도 증가할 것으로 추측할 수 있다. 그러나 본 연구의 결 과는 단순한 언어 자극 노출이 영아 발성 산출량의 증가와 관련되 지 않을 수 있다는 가능성을 보여주었다. 종합하면 현재로서는 본 연구와 선행연구의 결과를 근거로 양육자가 직접적으로 영아에게 말을 거는 것과 영아의 원시발성 산출량은 상관관계가 있으나 양 육자의 영아 지향어 산출 비율을 영아의 발성 증가 원인으로 결론 내리기 위해서는 더 많은 연구가 필요하다고 할 수 있다. 또한 원시 발성 산출과 성인 지향어의 관련성은 아직 명확하지 않으며, 성인 지향어에 간접적으로 노출된 경우 원시발성 산출을 오히려 감소시 킬 수도 있다는 본 연구의 결과를 염두하여 보다 심도 있는 연구가 필요하다.

일상생활에서는 연구실과 달리 영아 지향어의 산출 비율이 매 우 다를 수 있다. 영아 지향어가 산출되거나 그렇지 않은 두 경우 외 에도 더 세분화된 경우가 일반적이다. 따라서 본 연구에서는 5 가지 로 정도를 구분하여 양육자의 발화가 전혀 없는 경우부터 거의 5 분 에 가깝게 지속적으로 직접적인 발화가 산출된 경우를 나누어서 이에 따른 영아의 원시발성 산출 비율을 조사하였다. 영아 지향어 조건의 경우 전체적으로는 직접적인 발화가 증가함에 따라 영아의 원시발성 비율도 증가하는 추세를 보였다. 그러나 매우 흥미롭게도 영아 지향어의 산출 비율이 가장 높았던 조건에서 원시발성 비율 이 가장 높게 나타나지 않았다. 오히려 영아 지향어가 5 분 동안 중 간 정도로 산출되었을 때 영아가 원시발성을 더욱 많이 산출하였으 며, 이는 통계적으로도 유의미한 차이였다. 이와 같은 결과는 언어 자극의 양적인 증가에 따라 원시발성이 선형적으로 증가할 것으로 예상하는 일반적인 가설과 다른 결과이다. 따라서 본 연구 결과를 더욱 잘 해석하기 위해서는 양육자의 반응 및 자극과 아동의 발달 간에 선형적 관계가 아닌 곡선적 관계(curvilinear)를 주장하는 연 구들을 살펴볼 필요가 있다. 달리 말하면, 이는 아동의 발달을 촉
진하는 요소가 단순히 외부 자극의 양을 늘리는 것에 있는 것이 아 니고 가장 최적의 발달을 유도하는 적절한 범위 혹은 정도가 있다 는 관점이다.

양육자와 영유아의 협응(coordination)은 초기 영아와 양육자의 상호작용 및 영아의 발달에 관한 개념으로 이와 관련하여 양육자 의 반응성(responsiveness), 아동에 대한 민감성(sensitivity), 시간 적 협응(coordinated interpersonal timing, CIT) 등에 관한 많은 연구가 이루어지고 있다(Jaffe et al., 2001). 적절한 협응의 정도에 관 해서는 성인의 대화를 통한 연구에서 먼저 이루어졌는데 대표적으 로 세 가지의 가설들이 있다. Chapple (1970)은 두 명의 대화 파트너 (interlocutor)가 서로 상대방의 반응 시간이 예측 가능하며 매우 밀도가 높은 시간적 협응(high coordination)을 하게 되면 이러한 상호작용이 서로에게 보상으로 작용하고 긍정적인 감정반응을 도 출한다고 하였다. 반면, Gottman (1979)은 이 같은 밀도 높은 협응 은 오히려 심리적으로 스트레스가 될 수 있으며, 부정적인 감정을 유발한다고 주장하였다. Warner, Malloy, Schneider, Knoth와 Wilder (1987)는 중간 정도의 협응이 가장 긍정적인 상호작용에 영향을 준다고 보고하며, 극단적으로 밀도가 높거나 낮은 협응은 상호작 용에 부정적이라고 보고하며 중간정도의 반응 결과를 제안하였다. 성인을 대상으로 한 가설을 바탕으로 영아와 양육자와의 상호작용 및 협응에 관해 연구한 Jaffe 등(2001)은 4개월 영아와 성인(양육자 및 낯선 사람)의 발성 협응 정도와 12 개월의 애착 및 인지발달을 연 구하였다. 결과에 따르면 낮선 사람과의 중간 정도의 협응을 보인 영아가 가장 안정적인 애착을 형성하였으며, 인지발달의 경우에는 낯선 사람과의 밀도 높은 협응을 보인 영아가 표준 검사에서 높은 점수를 얻었다. Roe, Roe, Drivas와 Bronstein (1990)은 곡선 형태 의 관계를 보고하였는데, 중간 정도로 반응하고 대화를 했던 양육 자의 아동이 3 세와 5 세에 인지 검사에서 높은 수행력을 보였다. 이 처럼 협응이 성인 사이의 대화 및 영아의 발달에 밀접한 관련이 있 다는 것에는 연구자들 간에 이견이 없다. 그러나 구체적으로 영아의 발달에 영향을 주는 협응의 정도 혹은 최적의 반응 범위에 관해서 는 중간 정도의 반응이 적절하다는 연구들(Belsky, Rovine, \& Taylor, 1984; Isabella \& Belsky, 1991; Lester \& Seifer, 1990; Lewis \& Feiring, 1989)이 있지만 결론을 내리기에는 더 많은 연구가 필요하다.

위의 연구들은 발성 산출량을 분석한 본 연구와 직접 비교는 할 수 없지만, 중간 정도의 협응에 관한 결과를 근거로 본 연구에서 중 간 정도로 양육자가 발화를 하는 것이 오히려 영아에게 발성을 할 수 있는 기회와 시간을 주는 것으로 추론할 수 있다. Northrup과 Iverson (2015)의 연구에서는 언어발달 지연 영아와 일반 영아의 양 육자 발화에 대한 반응을 분석하였는데, 발달 지연 영아가 양육자 
에게 반응할 때 양육자의 발화와 유의미하게 중첩된다고 보고하였 다. 아직 의미 있는 단어를 산출하기 전의 영아는 구어 의사소통의 가장 중요한 특징 중의 하나인 적절한 주고받기를 배우고 상대와 내가 언제 대화를 개시해야 하는지를 배우는 것이 말-언어발달에 도 매우 중요하다. 이를 본 연구와 연관 지어 생각한다면, 대화의 기 초를 배우는 것은 선택적인 주의 집중과 적절한 발화 산출 등을 요 하는 그 자체로 매우 복잡한 협응을 요하는 과업이다(Northrup \& Iverson, 2015). 따라서 발달 지연 영아의 경우 적절하게 주고받기를 하기 보다는 양육자의 발화와 겹치는 경우가 많게 나타났다. 이러 한 이유로 양육자가 과도하게 혹은 밀도 높게 영아에게 발화를 산 출하는 경우가 아니라 오히려 영아에게 중간 정도로 발화를 산출 할 때가 영아에게 적절한 모델링을 제공하고 영아에게 반응할 수 있는 시간을 주어 대화의 기초인 적절한 주고받기를 배우는데 도 움이 되는 것으로 생각할 수 있다.

무표정 연구(Still-Face Paradigm [SFP], Tronick, Als, AdamsonWise, \& Brazelton, 1978)에서 일관되게 보고되는 결과와도 본 연구 결과를 연관지어 생각해 볼 수 있다. 양육자와의 일상적인 상호작용 후 양육자가 무표정과 무반응을 보이면 5개월 이후의 영아는 양육 자의 반응을 이끌어내기 위해 더 많은 원시발성을 산출한다(Franklin et al., 2014; Goldstein, Schwade, \& Bornstein, 2009). 본 연구의 중간 정도의 발화 산출이 무표정 연구에서의 무반응 단계와는 다 른 경우이지만 관련성(contingency)과 사회적 효능을 배워나가는 영아의 관점에서 양육자의 발화가 지속적으로 산출될 때보다 그렇 지 않을 경우, 양육자의 발화 산출을 촉진하기 위한 방법으로 영아 가 발성 산출을 증가시킬 수 있다는 가능성도 배제할수 없다.

마지막으로 연구 문제는 아니지만 본 연구를 통해 조사된 결과 에 대해 보고하고자 한다. 먼저 영아 지향어가 산출된 파일을 모두 합산하면 전체 파일의 $89 \%$ 가 된다. 비록 각 파일을 상세히 조사할 경우, 위에서 밝힌대로 영아 지향어의 산출 정도는 달라진다. 그러 나 영아에게 직접적으로 말을 건 파일이 관찰된 경우가 매우 높다 는 사실은 양육자가 영아기에도 직접 발화를 통해 상호작용을 지 속하려는 시도를 보여준다. Oller 등(2019) 역시 연구에서 영아 지 향어가 관찰된 파일이 전체의 $65 \%$ 이상이라고 보고하였다. 본 연 구에서는 이보다 높은 비율이 나타나 언어-문화적인 차이가 있을 가능성에 대해서도 생각해볼 수 있다. 동시에 두 연구 모두 영아의 원시발성은 호흡 단위를 근거로 분류하였으나, 양육자의 언어 환경 은 분석자가 녹음 자료를 듣고 직관적으로 영아 및 성인 지향어의 비율을 판단하였으므로 분석자의 영향도 고려해야 한다. 따라서 본 연구 및 선행연구의 방법은 기초적인 언어 환경 조사를 위해서 는 매우 유용하지만 보다 상세한 분석을 위하여 녹음 자료에 나타
난 영아 및 성인 지향어의 발화 수와 유형을 직접적으로 분석하는 추후 연구가 필요하다.

본 연구는 양육자의 영아 지향어 산출 비율이 가장 높을 때가 아 니라 절반 정도 차지하는 환경에서 영아의 원시 발성 산출량이 증 가하는 결과를 보여주었다. 양육자의 영아 지향어 산출과 상호작 용이 아동의 말-언어발달과 연관된다는 것은 알려진 사실이지만, 본 연구의 결과는 좀 더 나아가 이 두 변인 간의 선형적 관계가 아니 라 아동의 말-언어발달과 관련한 양육자의 최적의 발화 정도 연구 를 위한 기초를 제공한다. 본 연구의 결과를 바탕으로 적절한 협응 과 반응에 관한 보다 심화된 연구를 진행할 수 있으며, 임상 및 부 모교육에도 본 연구의 결과를 적용할 수 있을 것이다.

\section{REFERENCES}

Adair, J. K., Colegrove, K. S. S., \& McManus, M. E. (2017). How the word gap argument negatively impacts young children of Latinx immigrants' conceptualizations of learning. Harvard Educational Review, 87(3), 309-334.

Akhtar, N., Jipson, J., \& Callanan, M. A. (2001). Learning words through overhearing. Child Development, 72(2), 416-430.

Bateson, M. C. (1975). Mother-infant exchanges: the epigenesis of conversational interaction. Annals of the New York Academy of Sciences, 263(1), 101-113.

Belsky, J., Rovine, M., \& Taylor, D. (1984). The Pennsylvania infant and family development project, III: the origins of individual differences in infantmother attachment: maternal and infant contributions. Child Development, 55(3), 718-728.

Buder, E. H., Chorna, L. B., Oller, D. K., \& Robinson, R. B. (2008). Vibratory regime classification of infant phonation. Journal of Voice, 22(5), 553-564.

Buder, E. H., Jarmulowicz, L., \& Oller, D. K. (2013). Acquisition of the English voicing contrast by native Spanish-speaking children: phonological development in voice onset times. In B. Peter \& A. A. N. MacLeod (Eds.), Comprehensive perspectives on child speech development and disorders: pathways from linguistic theory to clinical practice (pp.326-342). Hauppage, NY: Nova Science Publishers, Inc.

Caskey, M., Stephens, B., Tucker, R., \& Vohr, B. (2011). Importance of parent talk on the development of preterm infant vocalizations. Pediatrics, 128(5), 910-916.

Chapple, E. D. (1970). Culture and biological man: explorations in behavioral anthropology. NY: Holt, Rinehart \& Winston.

Choi, H. S. (2012). Durational interaction of stops and vowels in English and Korean child-directed speech. Phonetics and Speech Sciences, 4(2), 61-70. 
Cooper, R. P., \& Aslin, R. N. (1990). Preference for infant-directed speech in the first month after birth. Child Development, 61(5), 1584-1595.

Delgado, R. E., Buder, E. H., \& Oller, D. K. (2010). Action analysis coding and training (AACT). Miami, FL: Intelligent Hearing Systems.

Dudley-Marling, C., \& Lucas, K. (2009). Pathologizing the language and culture of poor children. Language Arts, 86(5), 362-370.

Elmlinger, S. L., Schwade, J. A., \& Goldstein, M. H. (2019). The ecology of prelinguistic vocal learning: parents simplify the structure of their speech in response to babbling. Journal of Child Language, 46(5), 998-1011.

Fagan, M. K., \& Doveikis, K. N. (2017). Ordinary interactions challenge proposals that maternal verbal responses shape infant vocal development. Journal of Speech, Language, and Hearing Research, 60(10), 2819-2827.

Floor, P., \& Akhtar, N. (2006). Can 18-month-old infants learn words by listening in on conversations?. Infancy, 9(3), 327-339.

Forget-Dubois, N., Dionne, G., Lemelin, J. P., Pérusse, D., Tremblay, R. E., \& Boivin, M. (2009). Early child language mediates the relation between home environment and school readiness. Child Development, 80(3), 736-749.

Foushee, R., Griffiths, T., \& Srinivasan, M. (2016). Lexical complexity of childdirected and overheard speech: Implications for learning. Proceedings of the 38th Annual Conference of the Cognitive Science Society, 1697-1702.

Franklin, B., Warlaumont, A. S., Messinger, D., Bene, E., Nathani Iyer, S., Lee, C. C., ... \& Oller, D. K. (2014). Effects of parental interaction on infant vocalization rate, variability and vocal type. Language Learning and Development, 10(3), 279-296.

Gilkerson, J., Richards, J. A., Warren, S. F., Oller, D. K., Russo, R., \& Vohr, B. (2018). Language experience in the second year of life and language outcomes in late childhood. Pediatrics, 142(4), 1-11.

Goldstein, M. H., Schwade, J. A., \& Bornstein, M. H. (2009). The value of vocalizing: Five-month-old infants associate their own non cry vocalizations with responses from caregivers. Child Development, 80(3), 636-644.

Gottman, J. M. (1979). Marital interaction: experimental investigations. San Diego, CA:Academic Press.

Gros-Louis, J., West, M. J., Goldstein, M. H., \& King, A. P. (2006). Mothers provide differential feedback to infants' prelinguistic sounds. International Journal of Behavioral Development, 30(6), 509-516.

Ha, S., \& Oller, D. K. (2019). Canonical babbling in Korean-acquiring infants at 4-9 months of age. Communication Sciences \& Disorders, 24(1), 1-8.

Hart, B., \& Risley, T. R. (1995). Meaningful differences in the everyday experience of young American children. Baltimore, MD: PH Brookes.

Hoff, E. (2013). Interpreting the early language trajectories of children from
low-SES and language minority homes: implications for closing achievement gaps. Developmental Psychology, 49(1), 4-14

Isabella, R., \& Belsky, J. (1991). Interactional synchrony and the origins of infant-mother attachment: a replication study. Child Development, 62(2), 373-384.

Jaffe, J., Beebe, B., Feldstein, S., Crown, C. L., Jasnow, M. D., Rochat, P., \& Stern, D. N. (2001). Rhythms of dialogue in infancy: coordinated timing in development. Monographs of the Society for Research in Child Development, 66(2), 1-149.

Jang, H., \& Ha, S. (2020). Canonical babbling development in Korean-acquiring infants. Communication Sciences \& Disorders, 25(1), 104-112.

Kim, M. J. (2009). Acoustic characteristics of Korean stops in Korean childdirected speech. Phonetics and Speech Sciences, 1(3), 117-122.

Lee, J., \& Yim, D. (2017). A comparative study between the direct and overheard speech of primary caregiver of late talkers and typically developing infants. Communication Sciences \& Disorders, 22(2), 205-217.

Lee, Y., \& Ha, S. (2021). Parental responses to infants' prelinguistic vocalization. Communication Sciences \& Disorders, 26(1), 13-21.

Leung, C. Y., Hernandez, M. W., \& Suskind, D. L. (2020). Enriching home language environment among families from low-SES backgrounds: a randomized controlled trial of a home visiting curriculum. Early Childhood Research Quarterly, 50, 24-35.

Lester, B. M., \& Seifer, R. (1990). Antecedants of attachment. Proceedings of the origins and nature of attachment in infants and mother, Boston, MA.

Lewis, M., \& Feiring, C. (1989). Infant, mother, and mother-infant interaction behavior and subsequent attachment. Child Development, 60(4), 831837.

Liang, K. Y., \& Zeger, S. L. (1986). Longitudinal data analysis using generalized linear models. Biometrika, 73(1), 13-22.

Lopez, L. D., Walle, E. A., Pretzer, G. M., \& Warlaumont, A. S. (2020). Adult responses to infant prelinguistic vocalizations are associated with infant vocabulary: a home observation study. Plos One, 15(11), e0242232.

Maloney, E. A., Converse, B. A., Gibbs, C. R., Levine, S. C., \& Beilock, S. L. (2015). Jump-starting early childhood education at home: early learning, parent motivation, and public policy. Perspectives on Psychological Science, 10(6), 727-732.

Northrup, J. B., \& Iverson, J. M. (2015). Vocal coordination during early parent-infant interactions predicts language outcome in infant siblings of children with autism spectrum disorder. Infancy, 20(5), 523-547.

Oshima-Takane, Y., Goodz, E., \& Derevensky, J. L. (1996). Birth-order effects 
on early language development: do second born children learn from overheard speech?. Child Development, 67(2), 621-634.

Oller, D. K. (2000). The emergence of the capacity for speech. Mahwah, NJ: Erlbaum.

Oller, D. K., Buder, E. H., Ramsdell, H. L., Warlaumont, A. S., Chorna, L., \& Bakeman, R. (2013). Functional flexibility of infant vocalization and the emergence of language. Proceedings of the National Academy of Sciences, 110(16), 6318-6323.

Oller, D. K., Caskey, M., Yoo, H., Bene, E. R., Jhang, Y., Lee, C. C., ... \& Vohr, B. (2019). Preterm and full-term infant vocalization and the origin of language. Scientific Reports, 9(1), 1-10.

Orena, A. J., Byers-Heinlein, K., \& Polka, L. (2020). What do bilingual infants actually hear? Evaluating measures of language input to bilingual-learning 10-month-olds. Developmental Science, 23(2), e12901.

Pae, S., \& Kwak, K. C. (2011). Korean MacArthur-Bates communicative development inventories (K MB CDI). Seoul: Mindpress.

Park, W., \& Yim, D. (2015). The effectiveness of parental education via smartphone application on number of utterances and initiation ratio. Communication Sciences \& Disorders, 20(4), 500-509.

Parker, F. L., Boak, A. Y., Griffin, K. W., Ripple, C., \& Peay, L. (1999). Parentchild relationship, home learning environment, and school readiness. School Psychology Review, 28(3), 413-425.

Pegg, J. E., Werker, J. F., \& McLeod, P. J. (1992). Preference for infant-directed over adult-directed speech: evidence from 7-week-old infants. Infant Behavior and Development, 15(3), 325-345.

Roe, K. V., Roe, A., Drivas, A., \& Bronstein, R. (1990). A curvilinear relationship between maternal vocal stimulation and three-month-olds' cognitive processing: a cross-cultural phenomenon. Infant Mental Health Journal, 11(2), 175-189.

Romeo, R. R., Leonard, J. A., Robinson, S. T., West, M. R., Mackey, A. P., Rowe, M. L., \& Gabrieli, J. D. (2018). Beyond the 30-million-word gap: children's conversational exposure is associated with language-related brain function. Psychological Science, 29(5), 700-710.

Rowe, M. L. (2012). A longitudinal investigation of the role of quantity and quality of child-directed speech in vocabulary development. Child Development, 83(5), 1762-1774.

Sosa, A. V. (2016). Association of the type of toy used during play with the quantity and quality of parent-infant communication. JAMA Pediatrics,
$170(2), 132-137$.

Sultana, N., Wong, L. L., \& Purdy, S. C. (2019). Analysis of amount and style of oral interaction related to language outcomes in children with hearing loss: a systematic review (2006-2016). Journal of Speech, Language, and Hearing Research, 62(9), 3470-3492.

Suskind, D., Leffel, K. R., Hernandez, M. W., Sapolich, S. G., Suskind, E., Kirkham, E., \& Meehan, P. (2013). An exploratory study of "Quantitative Linguistic Feedback" effect of LENA feedback on adult language production. Communication Disorders Quarterly, 34(4), 199-209.

Tamis-LeMonda, C. S., Kuchirko, Y., Luo, R., Escobar, K., \& Bornstein, M. H. (2017). Power in methods: language to infants in structured and naturalistic contexts. Developmental Science, 20(6), e12456.

Trevarthen, C., \& Aitken, K. J. (2001). Infant intersubjectivity: research, theory, and clinical applications. Journal of Child Psychology and Psychiatry, 42(1), 3-48.

Tronick, E., Als, H., Adamson, L., Wise, S., \& Brazelton, T. B. (1978). The infant's response to entrapment between contradictory messages in face-toface interaction. Journal of the American Academy of Child psychiatry, 17(1), $1-13$.

Walle, E., \& Warlaumont, A. S. (2015). Infant locomotion, the language environment, and language Development: a home observation study. In Proceedings of the 37th Annual Meeting of the Cognitive Science Society, 25772582.

Warner, R. M., Malloy, D., Schneider, K., Knoth, R., \& Wilder, B. (1987). Rhythmic organization of social interaction and observer ratings of positive affect and involvement. Journal of Nonverbal Behavior, 11(2), 57-74.

Xu, D., Yapanel, U., Gray, S., Gilkerson, J., Richards, J., \& Hansen, J. (2008). Signal processing for young child speech language development. Paper presented at the 1st workshop on child, computer and interaction, Chania, Crete, Greece. Retrieved from www.lenafoundation.org/DownloadFile. aspx/pdf/SignalProcessing_ChildSpeech.

Yoo, H., Bowman, D. A., \& Oller, D. K. (2018). The origin of protoconversation: an examination of caregiver responses to cry and speech-like vocalizations. Frontiers in Psychology, 9, 1510.

Yoo, H., Oller, D. K., \& Ha, S. (2021). Early emergence and development protophones in the first year of life. Communication Sciences \& Disorders, 26(1), 1-12. 


\section{국문초록}

\section{영아기의 원시발성 산출과 가정 언어 환경}

\section{류현주 ${ }^{1} \cdot$ 하승희 ${ }^{2}$}

'University of Alabama, ${ }^{2}$ 한림대학교 언어청각학부, 한림청각언어연구소

배경 및 목적: 본 연구의 목적은 (1) 일상생활에서 관찰되는 영아 및 성인 지향어의 실제 산출 비율, (2) 영아 및 성인 지향어의 유무에 따른 원시발성의 산출 비율 변화, (3) 영아 및 성인 지향어 산출 비율 변화와 원시발성 산출 비율 간의 관련성을 조사하는 데 있다. 방법: 종단 연구를 위하여 LENA (Language ENvironment Analysis) 녹음기로 수집된 일반 영아 16명과 양육자의 발성 자료가 본 연구에 포 함되었다. 청지각적 기준에 따라 영아의 원시발성을 분류하고 분당 평균 산출량을 분석하였다. 양육자의 영아 및 성인 지향어 사용 정 도를 알아보기 위하여 분석자들이 각 녹음 파일의 언어 환경을 판단하였다. 연구 자료 분석은 Generalized Estimating Equations (GEE)를 사용하였다. 결과: 일상생활에서는 양육자가 영아에게 지속적으로 말을 걸거나 반응하기 보다는 상황에 따라 중간 정도로 반 응하였다. 영아 원시발성의 분당 평균 산출량은 영아 지향어가 산출되었을 때가 그렇지 않은 경우에 비해 통계적으로 유의미하게 높았 다. 성인 지향어의 경우는 원시발성 산출량 변화에 유의미한 영향은 없었다. 원시발성 분당 산출량은 영아 지향어가 각 녹음 파일의 중 간 정도로 산출되었을 때가 가장 높게 나타났다. 논의 및 결론: 성인 언어 자극의 양적 증가가 선형적으로 원시발성 산출량을 증가시키 지 않으며, 영아의 최적 발달에는 오히려 중간 정도의 자극과 반응이 도움이 될 수 있다는 가설에 관하여 논의하였다.

핵심어: 영아 지향어, 성인 지향어, 원시발성, 양육자, 언어 환경

\section{참고문헌}

김민정 (2009). 한국어 아동 지향어에 나타난 폐쇄음의 음향 음성학적 특성. 말소리와 음성과학, 1(3), 117-122.

류현주, D. Kimbrough Oller, 하승희 (2021). 한국 영아의 초기 원시발성 산출과 발성 발달. Communication Sciences \& Disorders, 26(1), 1-12. 박원정, 임동선 (2015). 발화분석 어플리케이션을 활용한 상호작용 증진 부모교육이 언어발달지연 아동과 부모의 발화 및 대화차례 개시에 미치는 영

향. Communication Sciences \& Disorders, 20(4), 500-509.

배소영, 곽금주 (2011). 한국판 맥아더-베이츠 의사소통발달평가(KM-B CDI). 서울: 마인드프레스.

이유란, 하승희 (2021). 언어이전기 아동 발성에 대한 부모의 반응. Communication Sciences \& Disorders, 26(1), 13-21.

이지연, 임동선 (2017). 말 늦은 유아(late talker)와 일반 유아주 양육자의 직접발화 및 간접발화 비교. Communication Sciences \& Disorders, 22(2), 205-217.

장현성, 하승희 (2020). 한국 아동의 음절성 옹알이 발달. Communication Sciences \& Disorders, 25(1), 104-112.

최한숙 (2012). Durational Interaction of Stops and Vowels in English and Korean Chil d-Directed Speech. 말소리와음성과학, 4(2), 61-70.

하승희, D. Kimbrough Oller (2019). 4-9개월 한국 아동의 음절성 옹알이. Communication Sciences \& Disorders, 24(1), 1-8.

\section{ORCID}

류현주(제1저자, 교수 https://orcid.org/0000-0002-1878-0768); 하승희(교신저자, 교수 https://orcid.org/0000-0003-2133-3720) 